\title{
GMR
}

\section{A proteomic approach to guarana seed and pericarp maturation}

\author{
A.L. Souza ${ }^{1}$, J.L. Lopez-Losano ${ }^{2}$, P.C.S. Angelo ${ }^{3}$, J.N. Souza-Neto ${ }^{1}$, \\ I.B. Cordeiro ${ }^{1}$, S. Astolfi-Filho ${ }^{1}$ and E.V. Andrade ${ }^{1}$ \\ ${ }^{1}$ Programa Multi-Institucional de Pós-Graduação em Biotecnologia, \\ Universidade Federal do Amazonas, Manaus, AM, Brasil \\ ${ }^{2}$ Fundação de Medicina Tropical do Amazonas, Manaus, AM, Brasil \\ ${ }^{3}$ Embrapa Café, Fundação Procafé, Varginha, MG, Brasil \\ Corresponding author: E.V. Andrade \\ E-mail: edandrade@ufam.edu.br
}

Genet. Mol. Res. 16 (3): gmr16039642

Received February 8, 2017

Accepted August 15, 2017

Published September 21, 2017

DOI http://dx.doi.org/10.4238/gmr16039642

Copyright (C) 2017 The Authors. This is an open-access article distributed under the terms of the Creative Commons Attribution ShareAlike (CC BY-SA) 4.0 License.

\begin{abstract}
Paullinia cupana Kunth var. sorbilis (Mart.) Ducke, the cultivated guarana plant, is native to the Amazon and has been valued for its medicinal, stimulant and energetic properties for centuries. The seeds are the main commercial product of the plant and the source of high amounts of purine alkaloids (caffeine and theobromine) and polyphenols (flavonoids, catechins, and tannins). Proteins involved in the development and maturation of guarana fruits in its native habitat are interesting issues for proteomics. This study presents the proteomic profile of the seed and pericarp of healthy guarana in different maturation stages. Protein contents were higher in the mature seed compared to other stages due to the accumulation of storage proteins - 11S globulins. Proteins selected for identification by mass spectrometry are mostly related to stress responses and defense and this is not unexpected for fast growing and differentiating reproductive tissues.
\end{abstract}

Key words: Paullinia; Sapindaceae; Fruit maturation; ROS; 2-D electrophoresis

Genetics and Molecular Research 16 (3): gmr16039642 


\section{INTRODUCTION}

Guarana is the fruit of the Amazonian plant species Paullinia cupana Kunth var. sorbilis (Mart.) Ducke, known as the guarana plant. This fruit has great economic potential because of its medicinal, stimulant and energetic properties (Kuskoski et al., 2005). The plant flowers in the driest months of the year in the Amazon region (July to September), and the fruit ripens 2-3 months after flowering (Escobar et al., 1984). Guarana is a dry dehiscent fruit that consists of a pericarp and an aril, which is an appendage rich in starch and seeds (1-3 seeds per fruit) (Poltronieri et al., 1995). The seed is the main commercial product of the plant due to its high caffeine content, which corresponds to 2.5 to $5.8 \%$ of the dry weight of the fruit, higher than that described for coffee (0.5 to 2.8\%) (Schimpl et al., 2014). Other metabolites with medicinal properties include flavonoids, which have powerful antioxidant properties (Chirinos et al., 2010), catechins, which assist in weight loss (Murase et al., 2002), tannins, which have important antioxidant and antiinflammatory activities (Mattei et al., 1998; Tobi et al. 2002), as well as others that contribute to the economic potential of this fruit. In addition, guarana has an important social role in rural areas in the Brazilian Amazon because it offers business opportunities for industries, compensation for thousands of producers and also contributes to keep people in rural areas.

Reports have indicated that guarana roasted seeds has aphrodisiac (Antunes et al., 2001), antimicrobial (Basile et al., 2005; Majhenič et al., 2007) and antioxidant (Mattei et al., 1998; Majhenič et al., 2007) activities. In addition, guarana has been shown to improve cognitive ability (Kennedy et al., 2004), mental fatigue (Kennedy et al., 2008) and stimulate the memory and the central nervous system (Espinola et al., 1997; Carlini, 2003), furthermore, it confers protection against gastric damage caused by alcohol (Campos et al., 2003), among other properties. An epidemiological study with an elderly riverine population in the municipality of Maués, the main producer of guarana in the State of Amazonas, revealed that habitual intake of guarana reduces the prevalence of hypertension, obesity and metabolic syndromes (Da Costa Krewer et al., 2011).

The broad economic potential of guarana combined with the interest in its bioproducts led to the study of the fruit transcriptome (Angelo et al., 2008), which generated more than fifteen thousand expressed sequence tags (ESTs) encoding proteins involved in various cellular functions. However, the information generated by genomics is not sufficient to make conclusions about the biology and physiology of organisms, despite providing a solid basis for further studies (Kersten et al., 2002), such as proteomics. Proteomic studies consolidate the information generated by genomics to evaluate metabolic disorders experienced by organisms according to the imposed conditions, whether biotic or abiotic, as it analyzes the final product of the genome. Therefore, the aim of this study was to conduct a proteomic analysis of healthy guarana at different stages of maturation, which will contribute to our understanding of the physiology of fruit maturation and also generate prospects for obtaining new biotechnologically important products. Two-dimensional electrophoresis was used to evaluate the protein expression profile at three different stages of maturation. Specific spots were selected for further identification by mass spectrometry, which delineated several metabolic pathways involved in tissue maturation.

\section{MATERIAL AND METHODS}

\section{Plant material}

The guarana fruits were obtained from the clone BRS-Amazonas, developed at

Genetics and Molecular Research 16 (3): gmr16039642 
EMBRAPA Western Amazon (Manaus, Amazonas, Brazil) and maintained in the Germplasm Bank of that institution $\left(3^{\circ} 06^{\prime} 07^{\prime \prime S}-60^{\circ} 01^{\prime} 30^{\prime \prime} \mathrm{W}\right)$. Three different maturation stages were analyzed: $15 \pm 7$ days after pollination (DAP), called the green stage; $30 \pm 7 \mathrm{DAP}$, called the intermediate stage; and $70 \pm 7 \mathrm{DAP}$, called the mature stage. The different organs (pericarp, aril with ovarian septum and debris and seeds with seed coats) were separated immediately after harvest, placed in dry ice and preserved at $-80^{\circ} \mathrm{C}$ until use. The proteomic analysis was conducted with seeds and pericarps from the three maturation stages, denominated green pericarp (GP), intermediate pericarp (IP), mature pericarp (MP), green seed (GS), intermediate seed (IS), and mature seed (MS). In total, six different experimental conditions were analyzed.

\section{Extraction of total protein and protein quantification}

To obtain the protein extracts, $1 \mathrm{~g}$ tissue from a pooled sample of each experimental condition was macerated with liquid nitrogen in the presence of $5 \%(\mathrm{w} / \mathrm{w})$ PVPP (polyvinylpolypyrrolidone) to neutralize phenolic compounds. Protein was extracted using the PVPP/SDS/Phenol method as described by Souza et al. (2014). The protein extracts were kept at $-20^{\circ} \mathrm{C}$ until use.

Total protein was quantified using the modified Lowry method (BCA Protein Assay - Bioagency) using extracts of tissues in each developmental stage solubilized in $0.5 \mathrm{~mL} 3 \mathrm{M}$ urea. Next, the reaction was monitored in a BioMate 3 spectrophotometer (Thermo Electron Corp., Madison, WI, USA) at $562 \mathrm{~nm}$. The amount of protein was estimated using the standard curve generated with known concentrations of bovine serum albumin (Sigma) $(\mathrm{y}=0.022 \mathrm{x}+$ $\left.0.0209 ; \mathrm{R}^{2}=0.9956\right)$.

\section{Two-dimensional electrophoresis and proteomic map analysis}

For the two-dimensional electrophoresis analysis, $0.3 \mathrm{mg}$ total protein was solubilized in $0.25 \mathrm{~mL}$ DeStreak Rehydration Solution (GE Healthcare) and 1\% IPG buffer, pH 3-11 (GE Healthcare). Samples were then applied to a 13-cm Immobiline DryStrip (GE Healthcare, $\mathrm{pH}$ 3-11 NL), rehydrated for $10 \mathrm{~h}$ and subjected to isoelectric focusing for $12 \mathrm{~h}$ in an Ettan IPGphor II system (Amersham Bioscience, Uppsala, Sweden) at $20^{\circ} \mathrm{C}$ with a continuous current of 50 $\mathrm{mA} /$ strip under the following conditions: $150 \mathrm{~V} / 2 \mathrm{~h}, 300 \mathrm{~V} / 2 \mathrm{~h}, 1000 \mathrm{~V} / 4 \mathrm{~h}$ (gradient), 8000 $\mathrm{V} / 2 \mathrm{~h}$ (gradient) and $8000 \mathrm{~V} / 2 \mathrm{~h}$. To perform the two-dimension electrophoresis, strips were equilibrated in a solution containing dithiothreitol $(0.5 \%)$ and iodoacetamide $(2.5 \%)$ (Görg et al., 1998) and placed on a 12\% SDS-PAGE gel in a Hoefer SE 600 Ruby system (Amersham Bioscience). The separation by molecular weight (second dimension) occurred at $250 \mathrm{~V}$ and $50 \mathrm{~mA}$ current per gel for approximately $4 \mathrm{~h}$. Next, the proteins were fixed on the gel $[10 \%$ $(\mathrm{v} / \mathrm{v})$ acetic acid, $40 \%(\mathrm{v} / \mathrm{v})$ methanol] for $30 \mathrm{~min}$ and subsequently stained with colloidal Coomassie Blue ( $8 \%$ ammonium sulfate, $0.8 \%$ phosphoric acid, $0.08 \%$ Coomassie blue G-250, $20 \%$ methanol) overnight. Gels were slowly destained in deionized water. Gel images were captured using Image Scanner (LabScan 5.0, GE Healthcare) at a resolution of 200 dpi and processed using Image Master 2D Platinum, version 6.0 (GE Healthcare). The salience and smooth values of 100 and 2, respectively, were used as parameters for automatic detection of spots, with subsequent manual corrections. The reference gel for each experimental condition was chosen based on comparisons among at least three gels of each condition with similarity equal to or greater than $70 \%$. The reference gel was that with the highest number of spots. Gels

Genetics and Molecular Research 16 (3): gmr16039642 
representing each condition were compared to each other to check for differences in expression according to the type of tissue and the maturation stage using Image Master Platinum 6.0. This analysis was based on the presence/absence of protein spots on the gels and was not associated with the expression rate among spots.

\section{Mass spectrometry}

For identification by mass spectrometry 180 spots were selected, which were exclusive of specific experimental conditions (tissue/maturation stage) or differentially expressed at least 1.5 -fold up or 1.5-fold down. The expression level of the spots analyzed by mass spectrometry was calculated based on the relative volume values $(\% \mathrm{~V}$, Image Master Platinum 6.0$)$, which were tested using the $t$-test $(\mathrm{P}<0.05)$ for the analysis of randomness of the expression volume of replica spots.

Protein spots were excised, reduced, alkylated, and submitted to in-gel digestion with trypsin (Sequencing Grade Modified Trypsin, lote: 24247001, Promega) according to Hanna et al. (2000). An aliquot $(4.5 \mu \mathrm{L})$ of the resulting peptide mixture was separated by C18 (75 $\mu \mathrm{m} \times 100 \mathrm{~mm}$ ) RP-nanoUPLC (nanoAcquity, Waters) coupled with a Q-Tof Ultima mass spectrometer (Waters Corporation, Milford, MA, USA) with nano-electrospray source at a flow rate of $0.6 \mathrm{~mL} / \mathrm{min}$. The gradient was $2-90 \%$ acetonitrile in $0.1 \%$ formic acid over $20 \mathrm{~min}$. The instrument was operated in the 'top three' mode, in which one MS spectrum is acquired followed by MS/MS of the top three most intense peaks detected. The resulting spectra were processed using Mascot Distiller 2.2.1.0, 2008, Matrix Science (MassLynx V4.1) and searched against the Guarana's EST database (available in http://www.ncbi.nih.gov) using Mascot, with carbamidomethylation as fixed modification, oxidation of methionine and one trypsin missed cleavage and a tolerance of $0.1 \mathrm{Da}$ for both precursor and fragment ions. Samples with no conclusive identification against the Guarana's EST database were analyzed against the NCBI's non-redundant database, limiting the taxonomic group to Viridiplantae (green plants, 3082218 sequences - July 2015). The identified proteins were grouped into functional categories according to the cellular process as described in the literature and analyzed in GO (Gene Ontology).

\section{RESULTS AND DISCUSSION}

\section{Protein yield and proteomic map analysis}

The proteomic profile of the guarana seed and pericarp was obtained for the three different maturation stages (Figure 1). For the pericarp, there was a reduction in both protein yield per gram of macerated tissue and number of spots on the gel as the tissue maturated (GP: $2.45 \mathrm{mg} / \mathrm{g}$ - 457 spots; IP: $1.70 \mathrm{mg} / \mathrm{g}$ - 444 spots; MP: $0.68 \mathrm{mg} / \mathrm{g}$ - 373 spots). This occurred because guarana is a dehiscent fruit and, when it reaches maturity, the pericarp opens and dries, exposing the seed.

The similarity between the proteomic profiles of pericarp at different stages of maturation was above 70\% (GP/IP: 74.36\%; IP/MP: 71.97\%; GP/MP: 70.12\%), which indicates no major changes in the gene expression profile upon maturation.

Regarding the seed, a reduction in diversity of protein spots on the gels was observed with tissue maturation, despite an increase in protein yield (GS: $2.40 \mathrm{mg} / \mathrm{g}$ - 488 spots; IS: 2.54

Genetics and Molecular Research 16 (3): gmr16039642 
$\mathrm{mg} / \mathrm{g}$ - 361 spots; MS: $3.06 \mathrm{mg} / \mathrm{g}$ - 348 spots). In addition, there were groups of protein spots that were very intense and unique to the MS condition in regions little "populated" in other proteomic maps (Figure 1F).
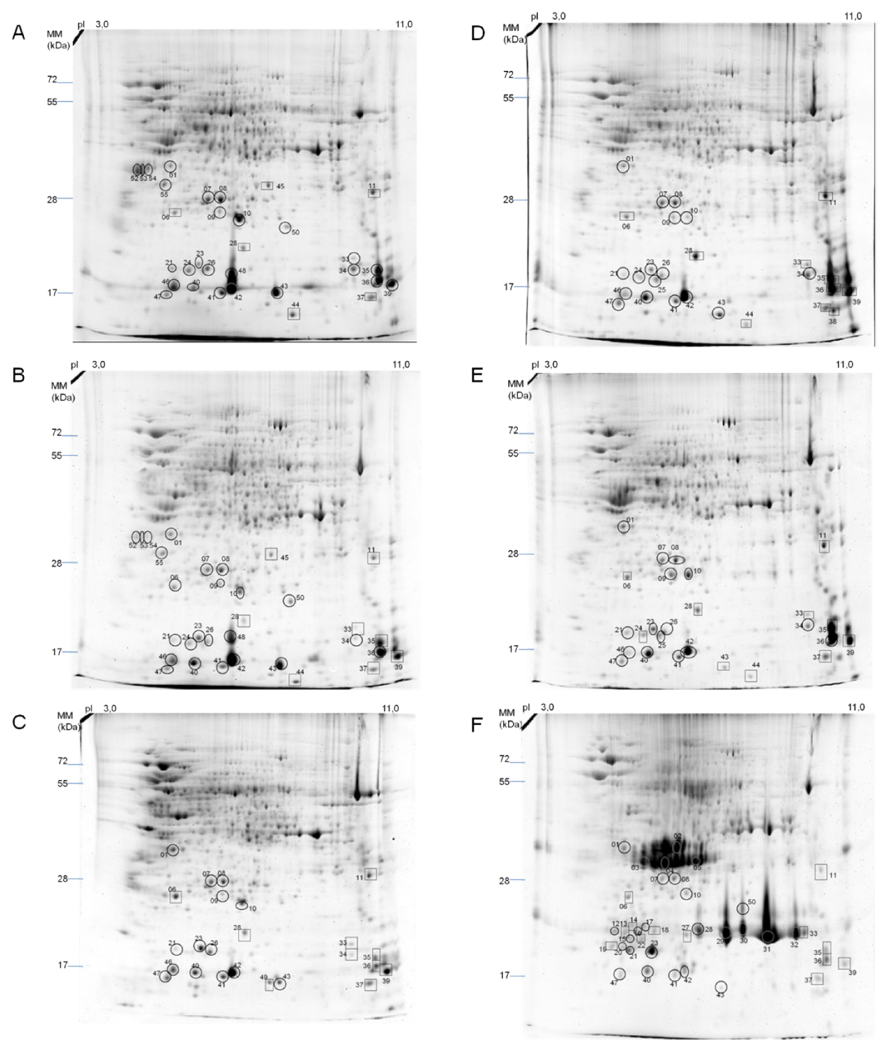

Figure 1. Proteomic profiles of guarana in pericarp and seed. A. Green pericarp (GP), 457 spots; B. intermediate pericarp (IP), 444 spots; C. mature pericarp (MP), 373 spots; D. green seed (GS), 488 spots; E. intermediate seed (IS), 361 spots; F. mature seed (MS), 348 spots. A total of $0.3 \mathrm{mg}$ protein was used on each gel, analyzed on 13$\mathrm{cm}$ strips (pH 3-11 NL) and run on 12\% SDS-PAGE stained with Coomassie blue. The spots selected for mass spectrometry analysis are indicated. Circles: conclusive identification; squares: non-conclusive identification.

Only GS and IS showed similarity above 70\%(GS/IS: 74.29\%). The similarities between GS/MS and IS/MS were 54.13 and $60.37 \%$, respectively, corresponding to approximately 160 exclusive spots in MS when compared to GS and 138 exclusive spots when compared to IS. This pattern may be associated with the differentiation of tissues along the maturation process. In this context, mature seeds are structures very specialized to accumulate reserves to supply the embryo and seedling with nutrients during germination up until the seedling can perform photosynthesis. This can explain the reduction in spot richness and simultaneous occurrence of high amounts of storage proteins.

\section{Protein identification by mass spectrometry}

Figure 1 shows the spots selected for identification by mass spectrometry based on 
the differential expression or exclusive expression between the experimental conditions (27 in GS, 26 in IS, 39 in MS, 32 in GP, 32 in IP, and 24 in MP). The spots with differential expression received the same number (1-55), but different letters, according to the maturation stage. Of these 180 spots selected and analyzed by MS, 123 (68.3\%) presented conclusive results when analyzed against the Guarana's EST database (Angelo et al., 2008). The spots with non-conclusive identification (57 spots, corresponding to $31.7 \%$ of the samples) were analyzed against the NCBI's non-redundant database, limiting the taxonomic group to Viridiplantae. Of these, no one obtained conclusive identification and the correspondent peptides, were designated as "non-conclusive" (Table 1). These results confirm the usefulness of a databank with nucleotide sequences derived from the same tissues for better use of the proteomic analysis results.

These 123 conclusively identified spots were found to represent 24 different proteins and isoforms that were classified according to cell processes enrolled based on the GO classification (Table 1).

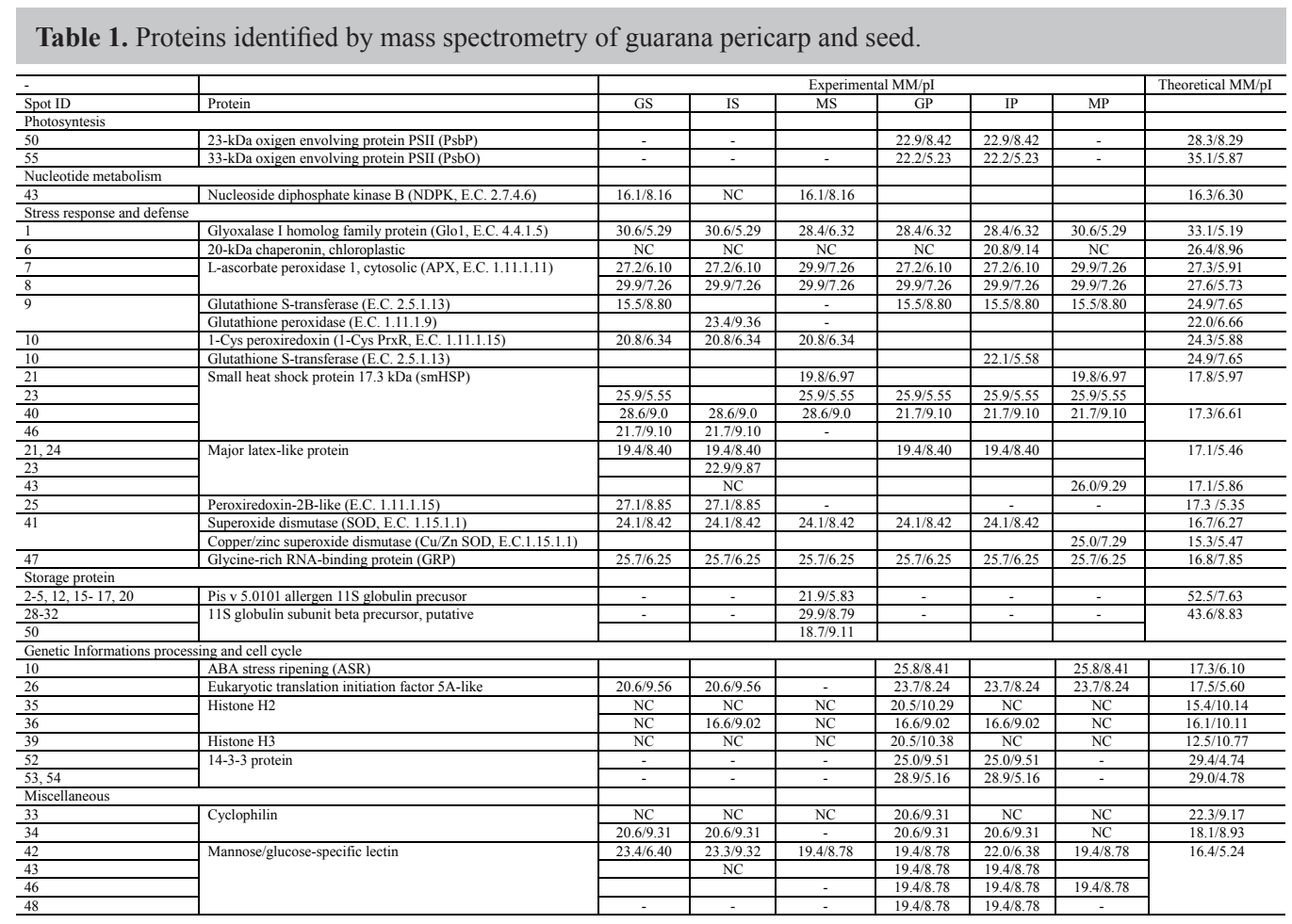

$(-)=$ spot absent; $\mathrm{NC}=$ non-conclusive spot. The empty field indicates that the spot corresponding to that number was identified as different protein in different conditions.

Proteins associated with the stress response and defense stand out of those conclusively identified in both seed (59\%) and pericarp (50\%) (Figure 2). The proteins involved in processing genetic information and cell cycle were more abundant in the pericarp $(28 \%)$ than in the seed (11\%). Those involved with nucleotide metabolism were identified only in the seed (6\%). In

Genetics and Molecular Research 16 (3): gmr16039642 
contrast, proteins involved in photosynthesis were detected only in the pericarp (11\%), and those associated with energy reserves were only detected in seeds (12\%), as expected.

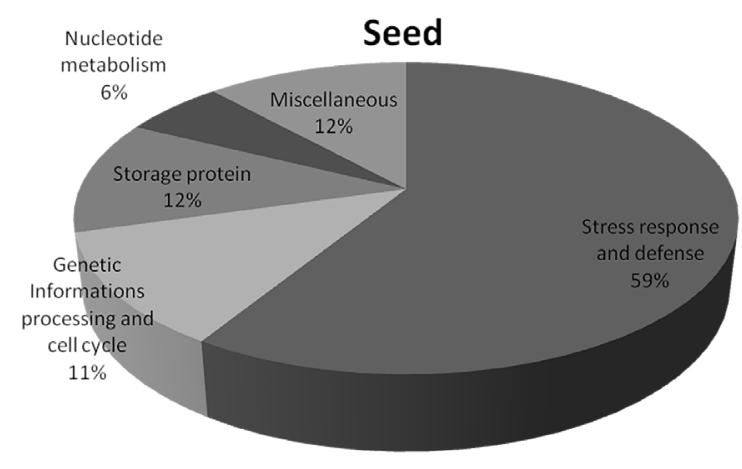

\section{Pericarp}

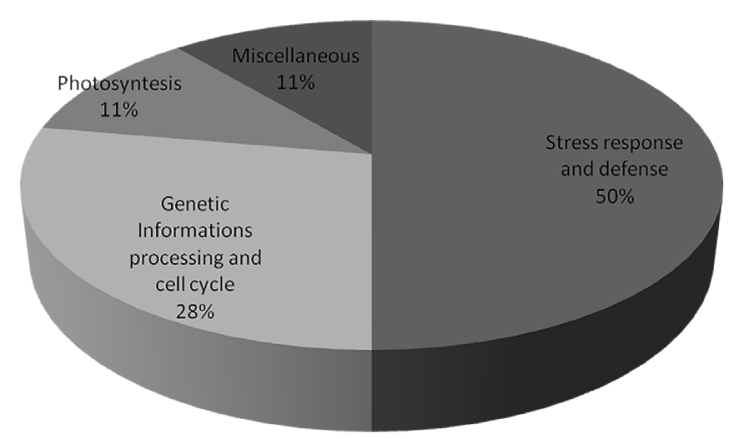

Figure 2. Functional classification of proteins identified by MS. The categorization was based on data from the literature and GO analysis. The percentages were obtained based on the number of identified proteins contained in the seed (17 proteins) and pericarp (18 proteins) groups independent of the developmental stage.

In the next paragraphs, proteins are grouped according to the GO function that they represent for better description and discussion of the results.

\section{Photosynthesis}

The proteins classified in this group correspond to $23-\mathrm{kDa}$ oxygen evolving protein from PSII (PsbP, spot 50) and 33-kDa oxygen evolving protein PSII (PsbO, spot 55). Both comprise the set of extrinsic proteins of the oxygen production complex of photosystem II, located on the luminal side of the thylakoid membrane of chloroplasts. They are described as important proteins in maintaining the optimal concentrations of manganese, chloride and calcium in the reaction center of photosystem II (Bricker and Frankel, 2011). In addition, they regulate the photosystem II and maintain the normal architecture of the thylakoid membrane, particularly regarding the integrity of grana stacks (Yi et al., 2009). The PsbO protein appears to be involved in stabilizing the tetramanganese cluster, required for the photoactivation process, whereas the PsbP protein is involved in increasing the binding affinity of $\mathrm{Cl}^{-}$and $\mathrm{Ca}^{2+}$

Genetics and Molecular Research 16 (3): gmr16039642 
ions, which are cofactors for the photosynthetic oxidation of water and also participates in stabilizing the manganese cluster (Bondarava et al., 2005; Bricker et al., 2012).

These proteins were expressed only in green and intermediate pericarp conditions. Although a significant increase in the expression rate (1.8-fold) was observed only for PsbP (spot 50) in the intermediate stage compared to the green stage (Figure 3), the protein PsbO (spot 55) displayed the same pattern of increase in expression but this up-regulation was not statistically significant (1.3-fold). This increase in expression occurred because the intermediate stage represents the cell rapid expansion stage where tissues intensify photosynthetic activities to support differentiation, development and accumulate biomass. These proteins were not expressed in mature pericarp because fruits do not have photosynthetically active chloroplasts in this stage, and the green color of chlorophyll is replaced by red-orange pigments that make the fruits more attractive to seed dispersers.
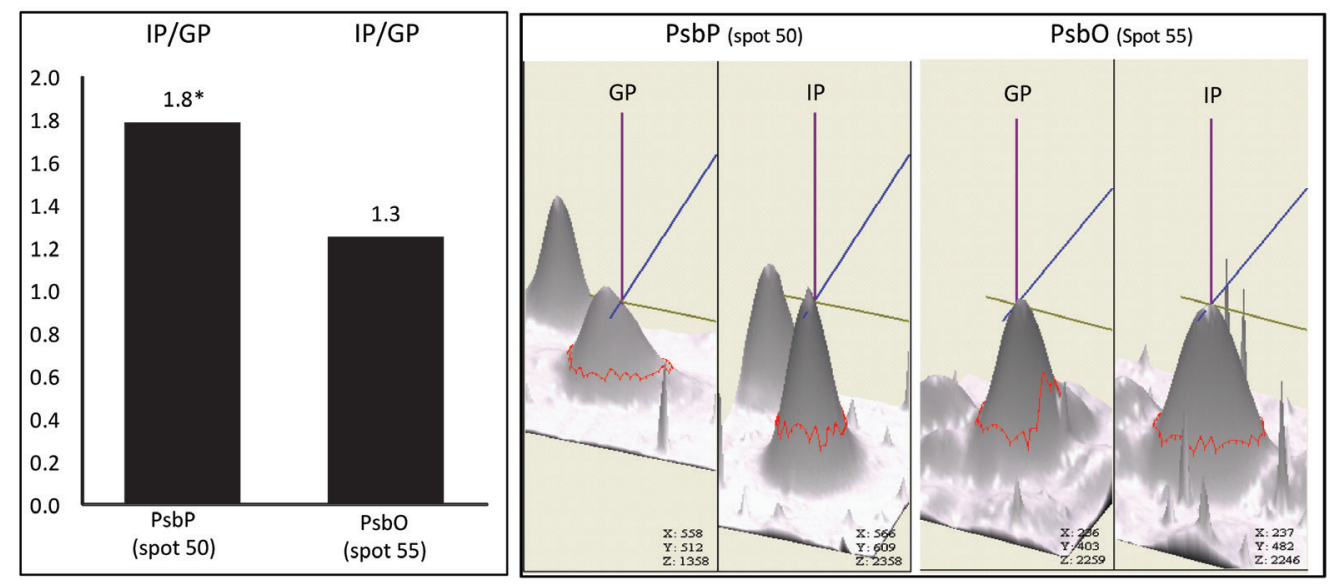

Figure 3. Comparative analysis of the expression of photosystem II extrinsic proteins enrolled in water reduction and oxygen evolution (PsbP and PsbO) in guarana pericarps. Ratio was calculated between the relative volume $(\% \mathrm{~V})$ of samples of the intermediate condition and green condition. $\% \mathrm{~V}$ values were analyzed and validated using the Student $t$-test $(\mathrm{P}<0.05)$. *Significant difference in expression [up $(+)$ and down $(-)$ regulation] between the conditions.

\section{Nucleotide metabolism}

In this group only the nucleoside diphosphate kinase (NDPK) protein (spot 43) was included and it was conclusively identified only in the green and mature stages of the seed. A clear reduction in the expression rate of -9.1-fold (Figure 4) was observed in the mature stage compared to the green stage. The identification of spot 43 was non-conclusive in the intermediate seed stage. NDPK is a ubiquitous enzyme found in all organisms and cell types that catalyzes the transfer of the $\gamma$-phosphoryl group from adenosine triphosphate (ATP) to nucleotide diphosphate (NDP) (Lascu and Gonin, 2000), maintaining the intracellular levels of all (d)NTPs required for nucleic acid biosynthesis (Moon et al., 2003). This protein appears to be involved in signal transduction processes associated with the regulation of cellular activities, such as proliferation, development and tissue differentiation (Otero, 2000; Dorion et al., 2006), which explains its occurrence mainly in the green condition. Variation in NDPK expression among different tissues and developmental stages has been reported (Escobar et al., 1984). 
Escobar Galvis et al. (2001) reported increased expression of mitochondrial NDPK (mtNDPK) in young leaves and reproductive tissues of pea compared to mature leaves. This occurred because young tissues exhibit high energy demand and hence high mitochondrial activity (Thompson et al., 1998) due to the intense cell division at this stage (Salmona et al., 2008).

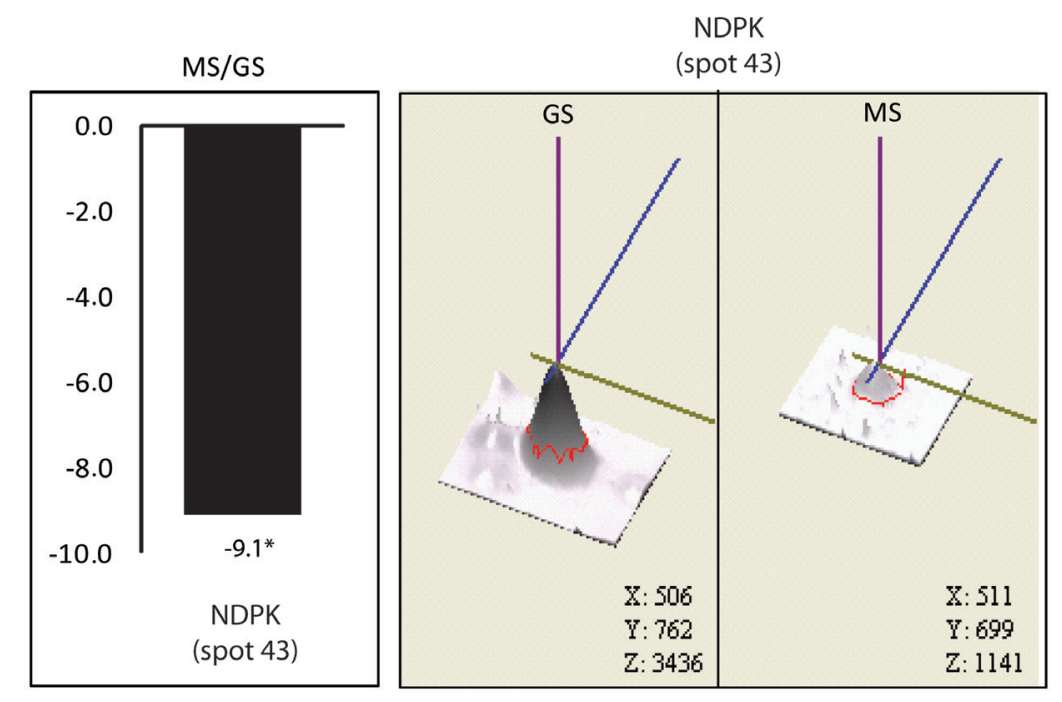

Figure 4. Comparative analysis of nucleoside-diphosphate kinase (NDPK) expression (spot 43) in guarana seeds. Ratio was calculated between the relative volume $(\% \mathrm{~V})$ of samples of the mature and green conditions. $\% \mathrm{~V}$ values were analyzed and validated using the Student $t$-test $(\mathrm{P}<0.05)$. *Significant difference in the expression [up $(+)$ and down (-) regulation] between the conditions.

Guarana seeds have high caffeine contents, which correspond to 2.5 to $5.8 \%$ of their dry weight (Schimpl et al., 2014). Although the present study did not identify the enzymes involved in caffeine synthesis, the xanthine skeleton of caffeine is derived from purine nucleotides (guanylate and adenylate) (Ashihara et al., 2008), and NDPK is involved in purine synthesis. As a purine alkaloid, caffeine is synthesized mainly in young leaves and immature fruit and then decreases gradually during the maturation of these organs (Ashihara et al., 2008; Schimpl et al., 2014). Schimpl et al. (2014) evaluated the expression levels of caffeine synthase (Paullinia cupana Caffeine Synthase - PcCS) in different guarana cultivars including BRS Amazonas used in the present study. Those authors found that the greatest expression of PcCS occurred in the seeds and was 7 to 20 times higher in green seeds than in other tissues and stages.

A high NDPK activity can certainly contribute to a high concentration of purine. High purine contents by its turn would more easily feed the purine alkaloid biosynthesis pathway. Then, it is meaningful that both - NDPK protein and caffeine - have peaks of concentration in guarana green seeds.

The non-identification of NDPK among the selected spots of pericarp does not mean that it is not expressed in this tissue, but that it was not among spots selected for identification.

\section{Stress response and defense}

The proteins categorized in the stress response and defense groups correspond to the

Genetics and Molecular Research 16 (3): gmr16039642 
majority of the proteins identified in the guarana seed (59\%) and pericarp (50\%). Similar results were observed in studies with grape (Fraige et al., 2015) and ripe mango pulp (Andrade et al., 2012). In general, living organisms synthesize a series of bioproducts during metabolic activity; when accumulated, these bioproducts have toxic effects on cells. These toxic substances include reactive oxygen species (ROS), which are highly reactive molecules wellknown for their ability to oxidize several biomolecules (such as proteins, nucleic acids, fatty acids, and pigments), modify cellular components and cause damage (Møller et al., 2007). Nevertheless, they act as important regulators of growth, development and defense pathways in plant cells (Neill et al., 2002; Schmidt and Schippers, 2015). ROS are produced mainly in tissues at early stages of development, such as cell histodifferentiation and expansion, given the high metabolic and respiratory rates related to this process (Wang et al., 2015). Mitochondria are the main producers of ROS in eukaryotic cells (Maxwell et al., 1999), and chloroplasts can also produce ROS, especially under high light conditions (Saito et al., 2011). The main enzymes involved in detoxifying the different cellular compartments of cells are: superoxide dismutase (SOD), ascorbate peroxidase (APX), glutathione peroxidase (GPX), catalase (CAT), and peroxiredoxin (PrxR). Along with ascorbic acid (ascorbate), tocopherol and glutathione, these enzymes promote a highly efficient mechanism of recycling and maintaining baseline $\mathrm{O}_{2} \bullet^{-}$(superoxide) and $\mathrm{H}_{2} \mathrm{O}_{2}$ (hydrogen peroxide) levels while minimizing the production of hydroxyl radicals $(\mathrm{HO} \bullet)$, which is the most harmful ROS as it reacts with all types of cellular components (Mittler et al., 2004; Møller et al., 2007). Among the enzymes that detoxify cells, catalase was the only one not detected in the present study.

SOD was present in all conditions analyzed (spot 41). In seed, the expression rate of SOD was reduced in the mature condition compared to the green $(-2.0)$ and intermediate conditions (-2.2), whereas the accumulation was not significant in the pericarp (Figure 5A). In studies with embryonic fibroblast cultures (NIH - 3T3) exposed to sodium nitroprusside (SNP), Bittencourt et al. (2013) demonstrated that the hydroethanolic extract of guarana reversed the cytotoxic effects of SNP, decreasing cell death, lipid peroxidation, DNA damage, and oxidative stress in cells and increasing SOD levels. APX was also detected in seed and pericarp (spots 07 and 08). In seed, a trend towards a reduction in APX expression with tissue maturation was observed (Figure 5B). In pericarp, APX accumulation occurred mainly in the intermediate condition, but a significant reduction in the expression rate was observed in the mature condition compared to the green condition (-2.8-fold, spot 08). Spot 9 was identified as different peroxidases in both tissues. GPX was identified in IS, whereas glutathione S-transferase (GST) was identified in GS and pericarp.

PrxR was detected only in the seed (spots 10 and 25) where a large increase in the expression rate was observed in the intermediate condition compared to the green condition (10.3-fold) (Figure 5C). This result corroborates Kim et al. (2011), who reported a significant increase in the expression of 1-Cys PrxR during the late stage of seed development. The GPX and PrxR families catalyze the reduction of peroxides and play an important role in antioxidant defense and stress signaling (Matamoros et al., 2010). Studies have demonstrated that 1-Cys PrxR has both molecular chaperone and peroxidase activities, suggesting that the peroxidase activity is important for gene expression during seed development and germination under normal conditions, whereas the molecular chaperone activity is crucial for tissue protection under stress conditions (Kim et al., 2011). Glyoxalase I (Glo I), involved in cellular detoxification, was also identified (spot 01) in all conditions studied. It is an important protein involved in the detoxification of methylglyoxal, a highly reactive aldehyde

Genetics and Molecular Research 16 (3): gmr16039642 
derived from the glycolytic pathway (Thornalley, 2003; Saito et al., 2011). In pericarp, Glo I accumulation (spot 01) gradually increased with maturation, which may be associated with the activation of pathways involved in the control of cellular stress under high light conditions, reduced water content in the pericarp and absence of chlorophyll (ripe fruit). In contrast, this accumulation was observed in the intermediate stage in seed, but it was significantly reduced in the mature condition (Figure 5D). The activation of detoxification enzymes of ROS may occur concomitantly with the acceleration of primary metabolism and photosynthetic pathways. Therefore, oxidative stress, as well as the expression of enzymes associated with its remediation, may decrease during seed development towards the final stage of maturation, when abscisic acid (ABA)-induced late embryogenesis proteins, such as dehydrins, are expressed, and the embryo is dormant.
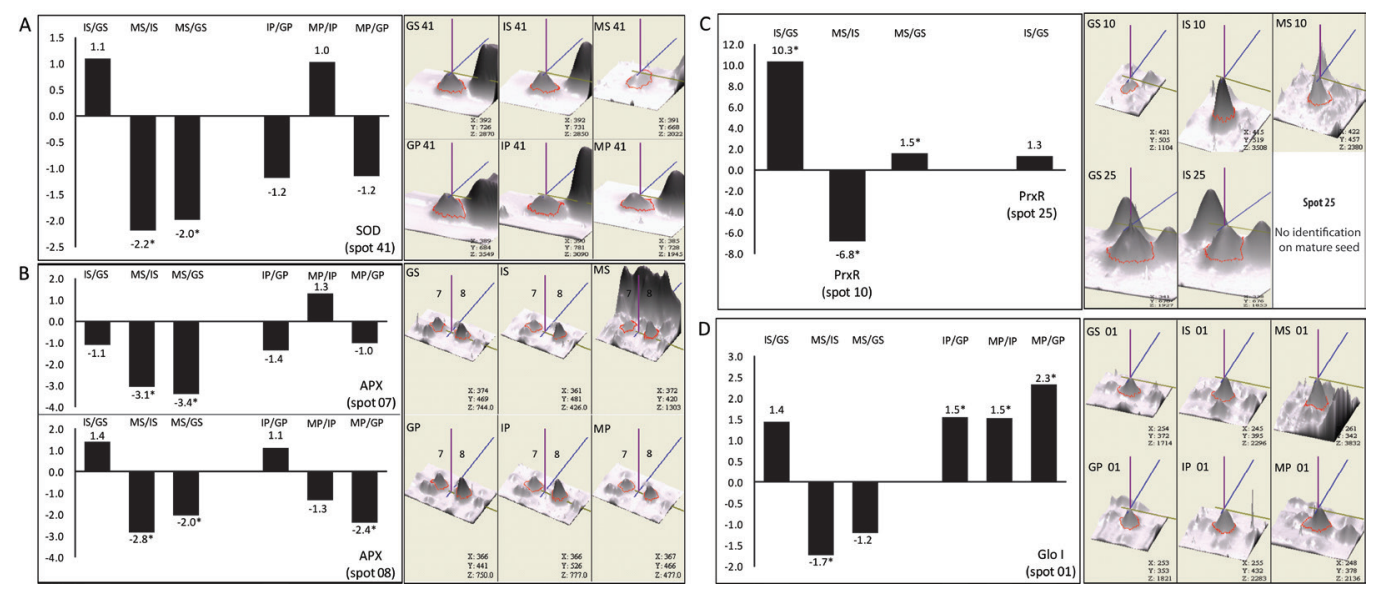

Figure 5. Expression rate of oxidative stress proteins. The graphs were based on the relative volume values $(\% \mathrm{~V})$ that were analyzed and validated using the Student $t$-test $(\mathrm{P}<0.05)$. *Significant difference in the expression [up $(+)$ and down (-) regulation] between the conditions.

The major latex-like protein (MLP - spots 21, 23, 24, and 43) was detected in GS, IS and in all stages of pericarp. This protein composes the aqueous matrix of latex, and its biological function is unknown (Sun et al., 2010). However, studies have shown similarity between MLP and pathogenesis-related proteins (PRP) (Osmark et al., 1998), and the pattern of expression suggests that MLP plays a role in the response to stress and defense (Radauer et al., 2008). Several members of the MLP/RRP (major latex protein/ripening-related protein) family are expressed in fruit, and their expression is up-regulated during ripening (Radauer et al., 2008). An increase (1.9-fold) in the expression rate of one of them was observed in seeds in the intermediate condition compared to the green condition (Figure 6A, spot 21). MLP expression in pericarp was not significantly different, remaining constant throughout maturation.

Wang et al. (2016) identified that a mutation in the mlp43 gene decreased ABA sensitivity during the germination of Arabidopsis thaliana seeds, with MLP43 functioning as an up-regulator of ABA in response to drought stress. The authors observed that the mlp43 mutants were sensitive to drought stress, while the $M L P 43$-overexpressed transgenic plants were drought tolerant. Typically, the ABA content is low in seeds during early embryogenesis 
and reaches higher levels in the intermediate and late stages of the process. This information corroborates the significant increase in MLP expression (1.9-fold) in the IS of guarana as it may be involved in the regulation of ABA expression, which in turn regulates seed dormancy and embryo development (Nakashima and Yamaguchi-Shinozaki, 2013).

Chaperonin (cpn10-spot 06), conclusively identified only in the intermediary pericarp condition, is a chloroplast protein that composes a protein complex that guides the perfect folding and assembly of other proteins (Vitlin Gruber et al., 2013). In turn, small heat shock proteins (smHSP - spots 21, 23, 40, and 46) are conserved in species and play an important role in heat stress, drought stress, and contamination with metal ions (Klein et al., 2014). The expression of smHSP (spot 23) was significantly higher in the mature stage of both seed and pericarp (Figure 6B), whereas the expression of smHSP (spot 40) was higher in the IP and reduced in the MS compared to the other stages (Figure 6C). In studies with mango, Andrade et al. (2012) reported a reduction in smHSP expression during fruit ripening. Chen et al. (2014) conducted studies with thermotolerant rice cultivars and observed upregulation of five smHSPs in seedlings and during the anthesis in response to thermal stress compared with a thermosensitive cultivar. These findings suggest that these proteins may be used as biomarkers to select cultivars that can avoid thermal stress.

Glycine-rich RNA-binding protein (GRP - spot 47), identified in all conditions, is included in a small family of proteins that contain two domains: an RNA-recognition motif at the N-terminus and the C-terminal region that consists of more than $70 \%$ Gly residues (Burd and Dreyfuss, 1994). Its expression decreased during seed maturation, while increased expression was observed in pericarp during maturation (Figure 6D). Several studies have described an increased abundance of these proteins under stressful conditions, such as injury, heat, drugs, ABA, and others (Bergeron et al., 1993; Carpenter et al., 1994; Kim et al., 2007). GRP is a class of RNA-binding proteins involved in post-transcriptional regulation (Lorković, 2009) and also has RNA chaperone activity under abiotic stress conditions (Kim et al., 2007). In studies with transgenic rice plants expressing GRP from Arabdopsis thaliana (AtGRP), Yang et al. (2014) observed that, despite other phenotypic similarities, transgenic plants showed higher grain yield than wild plants under abiotic stress conditions, suggesting that GRPs can be used to improve the yield potential of crops under stress.
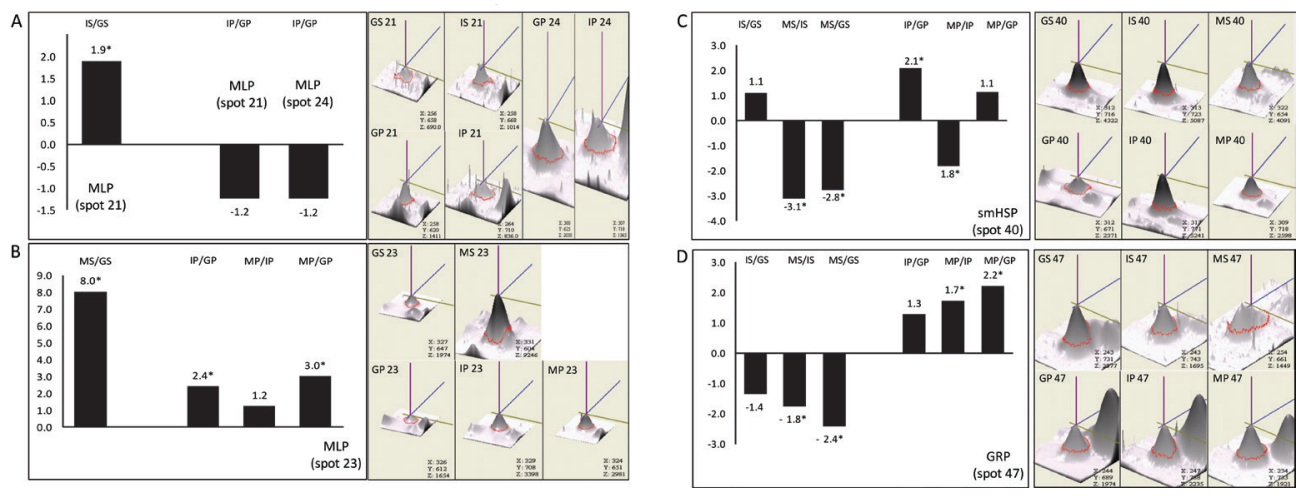

Figure 6. Expression rate of stress response and defense proteins. The graphs were based on the relative volume values $(\% \mathrm{~V})$ analyzed and validated using the Student $t$-test $(\mathrm{P}<0.05)$. ${ }^{*}$ Significant difference in the expression [up $(+)$ and down (-) regulation] between the conditions.

Genetics and Molecular Research 16 (3): gmr16039642 


\section{Storage proteins}

Mature seeds are composed of approximately $80-90 \%$ storage proteins that are accumulated in discrete vesicles called protein bodies, which are important sources of amino acids for plants during germination and early seedling development (Chua et al., 2008). Storage proteins are classified into four groups according to their solubility: soluble in water (albumin), saline diluent (globulins) water/alcohol solution (prolamines), and acid or alkali diluent (glutelin) (Shewry et al., 1995; Chua et al., 2008). Storage proteins are also particularly important for determining seed quality for several purposes and uses (Shewry et al., 1995).

The proteins of this group were identified only in the mature seed condition (MS) in spots 2 to $5,12,15$ to 17, 20, 28 to 32 and 50. They were identified as precursors for 11S globulin. Globulins are the most widely distributed storage proteins, being present in both dicotyledonous and monocotyledonous plants. Proteins of the 11S family consist of six subunit pairs that interact non-covalently. Each of these six pairs consists, alternately, of an acidic subunit (approximately $40 \mathrm{kDa}$ ) and a basic subunit (approximately $20 \mathrm{kDa}$ ) connected by a disulfide bridge (Shewry et al., 1995). This explains the presence of two regions heavily populated by proteins on the gel of mature seed, which differentiates the proteomic profile of mature seeds from the other conditions under analysis (Figure 1). The proteins of the 11S family, also called legumins, are the most abundant globulins in coffee seed. Rogers et al. (1999) estimated that these proteins comprised approximately $45 \%$ of the total protein in coffee grain.

Contribution of legumin-like proteins and vicilins, which are 7S globulins, in defense against pathogens, presenting insecticidal (Coelho et al., 2010) and antifungal (Jimenez-Lopez et al., 2016) activities has been demonstrated besides its role as storage protein. As discussed, globulins were detected in great content and specifically in mature seed (Figure 1 and Table 1). Investigating how $11 \mathrm{~S}$ globulin cooperates for protection during the guarana seed development could be an exciting area of research.

\section{Genetic information processing and cell cycle}

In plants, the 14-3-3 protein regulates a variety of biological processes, including primary metabolism, response to both biotic and abiotic stress, plant development, proton pumps and ion channels, signal transduction and others (Fulgosi et al., 2002; Roberts, 2003; Denison et al., 2011). In a proteomic study of mango, Andrade et al. (2012) detected the accumulation of 14-3-3 proteins during fruit ripening, which may be associated with changes in membrane integrity and pulp softening. It was present only in the green and intermediate pericarp of guarana (spots 52, 53 and 54), with reduced expression observed with maturation (Figure 7A). The 14-3-3 protein may be associated with primary metabolism and signal transduction in early stages of development because it affects the activity of several enzymes and ion channels crucial to plant biochemistry (Roberts, 2003).

Eukaryotic translation initiation factor 5A (eIF5A) plays an important role in the translation of mRNAs required for both cell division and cell death (Thompson et al., 2004). In a study about cherry tomato ripening, Faurobert et al. (2007) described the presence of two peaks of eIF5A expression: during the phase of intensive cell division and during the ripening stage. This protein was also described by Bianco et al. (2009) in the analysis of the strawberry proteome. This last study showed eIF5A accumulation in mature fruits, and it was suggested that the protein might be associated with fruit senescence. The results obtained with guarana

Genetics and Molecular Research 16 (3): gmr16039642 
corroborate with both studies. The eiF5A protein was identified in green and intermediate seeds (absent in MS), and in all stages of pericarp (spot 26) without differences in expression among the stages, but a slight accumulation was observed in mature pericarp (Figure 7B), a stage characterized by drying and cell death in septa zones where fruit dehiscence occurs.

Histones (spots 35, 36 and 39), conclusively identified only in IS (spot 36), GP (spots 35, 36 and 39), and IP (spot 36), are conserved proteins present in the nucleus of eukaryotic cells. They are basic and rich in lysine (Lys) and arginine (Arg) residues that are associated with DNA in a highly organized manner, forming structures called nucleosomes (Horn and Peterson, 2002), which play an important role in regulating gene expression (Tariq and Paszkowski, 2004; Lee et al., 2016) and DNA compaction during chromatin organization. The factors that regulate the positioning of nucleosomes control chromatin conformation and DNA methylation (Fransz and de Jong, 2011).

The ASR protein (ABA, stress and ripening) is an ABA-stress- and ripening-induced protein. It was identified in the pericarp in the green and mature conditions (spot 10). This protein is small, basic and hydrophilic due to its large amount of His, Lys and Glu residues (Çakir et al., 2003). Its nuclear localization and DNA binding capacity (Iusem et al., 1993) suggest that this protein can regulate gene transcription under certain conditions, such as in the presence of ABA, stress and during tissue maturation. Although its biological function is not well known, ASR is involved in developmental processes, such as senescence, fruit ripening, pollen maturation, as well as responses to abiotic stress conditions, such as water deficiency, salt, cold and light limitation (Huang et al., 2000; Maskin et al., 2001; Jeanneau et al., 2002; Kalifa et al., 2004; González and Iusem, 2014). In guarana, ASR protein expression was reduced in the mature condition compared with green pericarp condition (-2.8-fold; Figure 7C), and its expression pattern may be associated with a reduction in translocation of reserves to the seed at the end of development.

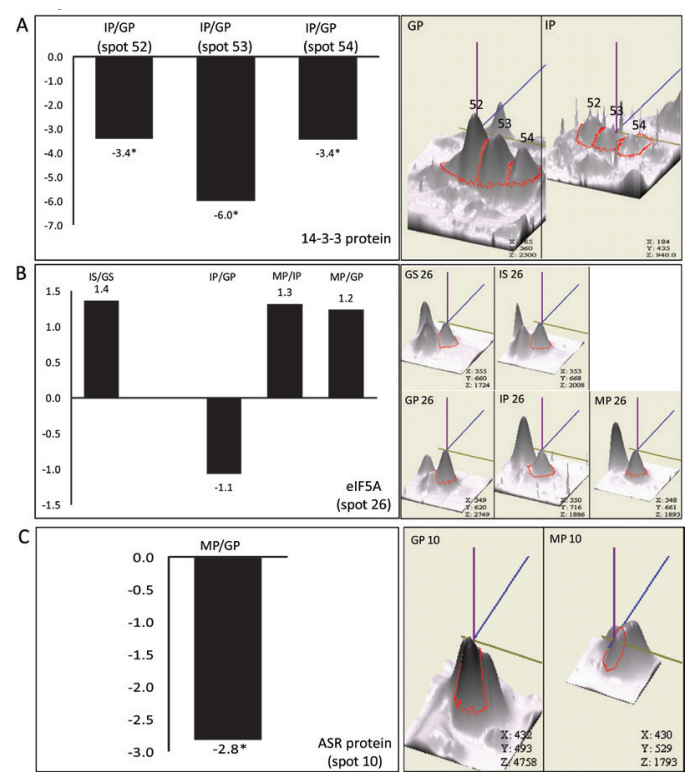

Figure 7. Expression rate of genetic information processing and cell cycle. The graphs were based on the relative volume values $(\% \mathrm{~V})$ analyzed and validated using the Student $t$-test $(\mathrm{P}<0.05)$. ${ }^{*}$ Significant difference in the expression [up (+) and down (-) regulation] between the conditions.

Genetics and Molecular Research 16 (3): gmr16039642 


\section{Miscellaneous}

Cyclophilin (spot 34), absent in MS and with non-conclusive identification in MP, has peptidyl-prolyl cis-trans isomerase (PPIase) enzymatic activity in plants, fungi and bacteria, catalyzing the rotation on the N-terminal peptide bond of the proline residue (Trandinh et al., 1992). It can also act as an ATP-independent molecular chaperone (Ellis and van der Vies, 1991). Sekhar et al. (2010) observed that a transgenic Arabidopsis line expressing Cajanus cajan cyclophilin (CcCYP) exhibited higher tolerance against adverse conditions, such as drought, salinity and high temperatures, compared to the control plant and exhibited enhanced PPIase activity under stress conditions, demonstrating the implicit role of this protein in conferring tolerance to plants under abiotic stress conditions. The guarana plant flowers in the driest months of the year (July to September), apparently following a period of water deficit, and the fruit ripens 2-3 months after flowering (Escobar et al., 1984; Poltronieri et al., 1995), under high temperatures, which favors the expression of proteins involved in the stability of biological systems under extreme temperature and drought.

Lectins were mainly identified in the pericarp as spots $42,43,46$, and 48 , with a high expression rate that decreased with maturation (Figure 8). These proteins can recognize and reversibly bind to different carbohydrates and are widely distributed in nature (Cavada et al., 1994). Lectins are usually present in large quantities in storage organs and seeds, which are tissues particularly vulnerable to pathogens or insects (Peumans and Van Damme, 1995). Many lectins are synthesized as inactive precursors, becoming active only after sequestration in specialized organelles, suggesting their involvement in plant defense against phytopathogenic microorganisms, nematodes and insects (Vandenborre et al., 2011). Its insecticidal activity is due to the affinity of plant lectins to carbohydrate structures present in the midgut of insects (Bolognesi et al., 2008), affecting the functioning of their physiological processes. Oliveira et al. (2015) investigated the effects of Dioclea violacea lectin (DVL) on the larval development of Anagasta kuehniella and observed that chronic exposure to DVL affected larval development without affecting survival. Its entomotoxic activity was facilitated by several factors, such as resistance of the lectin to proteolytic digestion, binding to chitin molecules present in the peritrophic membrane of the midgut of larvae and an effect on the activity of digestive enzymes.

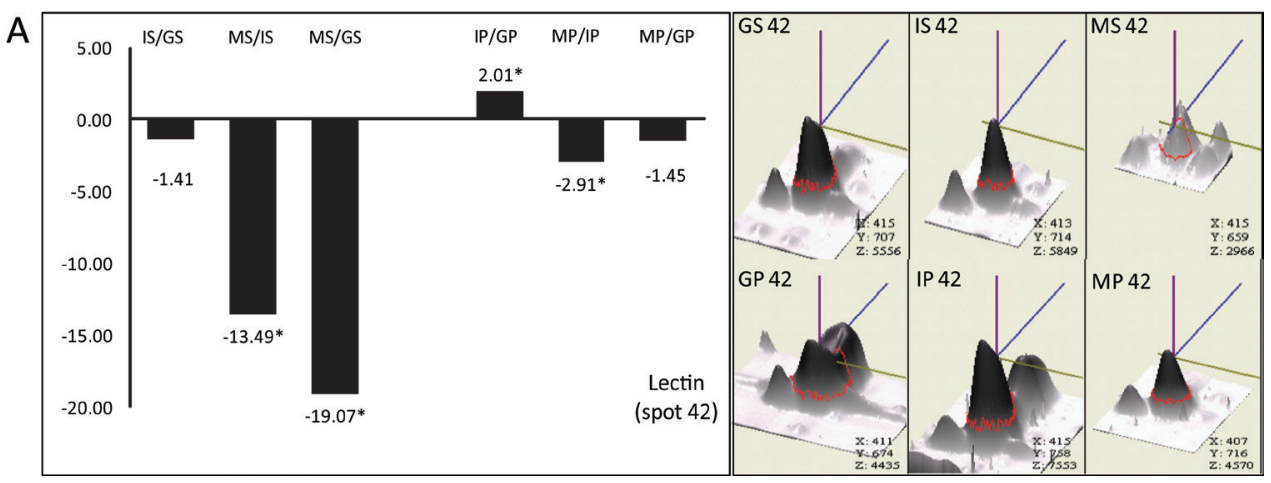

Figure 8. Expression rate of lectins. The graphs were based on the relative volume values $(\% \mathrm{~V})$ analyzed and validated using the Student $t$-test $(\mathrm{P}<0.05)$. *Significant difference in the expression $[u p(+)$ and down $(-)$ regulation] between the conditions.

Genetics and Molecular Research 16 (3): gmr16039642 


\section{CONCLUSIONS}

In general, there was a reduction in the expression of all proteins in the mature condition, especially the seed. This reduction occurs because, when the fruit reaches maturity, the tissues are already developed and fully differentiated, the reserve deposits are already accumulated, and the metabolic activities and respiratory rates enter a basal stage. Guarana is a dehiscent fruit; therefore, the pericarp opens and dries, and the seeds carrying the dormant embryos are ready to be dispersed to continue the plant cycle. The analysis method used in this study did not allow for the identification of proteins involved in the synthesis of secondary compounds, such as polyphenols (tannins and catechins) and purine alkaloids (methylxanthines), which are abundant in guarana and add valuable economic potential to the fruit. However, the proteins identified in this study allowed for an overview of the physiological changes that occur during development and maturation of the fruit, as well as the large number of proteins and metabolic pathways that allow the species to adapt to the environment. Further studies on the metabolic pathways involved in the production of secondary metabolites are necessary.

\section{ACKNOWLEDGMENTS}

Research supported by CNPq, FAPEAM, CAPES, and FINEP. This study was carried out by the Amazon Proteomic Network (PROTEAM). We thank the researcher Firmino José do Nascimento Filho (EMBRAPA Western Amazon) for helping in the estimation of fruit ripening stages and the Spectrometry Laboratory Mass of the National Biosciences Laboratory - LNBio, CNPEM - ABTLuS, Campinas, Brazil, for its support with the mass spectrometry analysis.

\section{REFERENCES}

Andrade JdeM, Toledo TT, Nogueira SB, Cordenunsi BR, et al. (2012). 2D-DIGE analysis of mango (Mangifera indica L.) fruit reveals major proteomic changes associated with ripening. J. Proteomics 75: 3331-3341. https://doi. org/10.1016/j.jprot.2012.03.047

Angelo PCS, Nunes-Silva CG, Brígido MM, Azevedo JSN, et al.; Brazilian Amazon Consortium for Genomic Research (REALGENE) (2008). Guarana (Paullinia cupana var. sorbilis), an anciently consumed stimulant from the Amazon rain forest: the seeded-fruit transcriptome. Plant Cell Rep. 27: 117-124. https://doi.org/10.1007/s00299-007-0456-y

Antunes E, Gordo WM, de Oliveira JF, Teixeira CE, et al. (2001). The relaxation of isolated rabbit corpus cavernosum by the herbal medicine Catuama and its constituents. Phytother. Res. 15: 416-421. https://doi.org/10.1002/ptr.861

Ashihara H, Sano H and Crozier A (2008). Caffeine and related purine alkaloids: biosynthesis, catabolism, function and genetic engineering. Phytochemistry 69: 841-856. https://doi.org/10.1016/j.phytochem.2007.10.029

Basile A, Ferrara L, Pezzo MD, Mele G, et al. (2005). Antibacterial and antioxidant activities of ethanol extract from Paullinia cupana Mart. J. Ethnopharmacol. 102: 32-36. https://doi.org/10.1016/j.jep.2005.05.038

Bergeron D, Beauseigle D and Bellemare G (1993). Sequence and expression of a gene encoding a protein with RNA-binding and glycine-rich domains in Brassica napus. Biochim. Biophys. Acta 1216: 123-125. https://doi. org/10.1016/0167-4781(93)90047-H

Bianco L, Lopez L, Scalone AG, Di Carli M, et al. (2009). Strawberry proteome characterization and its regulation during fruit ripening and in different genotypes. J. Proteomics 72: 586-607. https://doi.org/10.1016/j.jprot.2008.11.019

Bittencourt LS, Machado DC, Machado MM, Dos Santos GFF, et al. (2013). The protective effects of guaraná extract (Paullinia cupana) on fibroblast NIH-3T3 cells exposed to sodium nitroprusside. Food Chem. Toxicol. 53: 119-125. https://doi.org/10.1016/j.fct.2012.11.041

Bolognesi R, Terra WR and Ferreira C (2008). Peritrophic membrane role in enhancing digestive efficiency. Theoretical and experimental models. J. Insect Physiol. 54: 1413-1422. https://doi.org/10.1016/j.jinsphys.2008.08.002

Bondarava N, Beyer P, Krieger-Liszkay A (2005). Function of the $23 \mathrm{kDa}$ extrinsic protein of Photosystem II as a manganese binding protein and its role in photoactivation. Biochim. Biophys. Acta Bioenerg. 1708: 63-70.

Genetics and Molecular Research 16 (3): gmr16039642 
Bricker TM and Frankel LK (2011). Auxiliary functions of the PsbO, PsbP and PsbQ proteins of higher plant Photosystem II: a critical analysis. J. Photochem. Photobiol. B 104: 165-178. https://doi.org/10.1016/j.jphotobiol.2011.01.025

Bricker TM, Roose JL, Fagerlund RD, Frankel LK, et al. (2012). The extrinsic proteins of Photosystem II. Biochim. Biophys. Acta Bioenerg. 1817: 121-142.

Burd CG and Dreyfuss G (1994). Conserved structures and diversity of functions of RNA-binding proteins. Science 265: 615-621. https://doi.org/10.1126/science.8036511

Çakir B, Agasse A, Gaillard C, Saumonneau A, et al. (2003). A grape ASR protein involved in sugar and abscisic acid signaling. Plant Cell 15: 2165-2180. https://doi.org/10.1105/tpc.013854

Campos AR, Barros AIS, Santos FA and Rao VSN (2003). Guarana (Paullinia cupana Mart.) offers protection against gastric lesions induced by ethanol and indomethacin in rats. Phytother. Res. 17: 1199-1202. https://doi.org/10.1002/ptr.1212

Carlini EA (2003). Plants and the central nervous system. Pharmacol. Biochem. Behav. 75: 501-512. https://doi. org/10.1016/S0091-3057(03)00112-6

Carpenter CD, Kreps JA and Simon AE (1994). Genes encoding glycine-rich Arabidopsis thaliana proteins with RNAbinding motifs are influenced by cold treatment and an endogenous circadian rhythm. Plant Physiol. 104: 1015-1025. https://doi.org/10.1104/pp.104.3.1015

Cavada BS, Grangeiro TB, Ramos MV, Crisostomo CV, et al. (1994). Lectin from Dioclea guianensis var. lasiophylla Duke seed mobilization during germination and seedling growth in the dark. Rev. Bras. Fisiol. Vegetal 6: 21-25.

Chen X, Lin S, Liu Q, Huang J, et al. (2014). Expression and interaction of small heat shock proteins (sHsps) in rice in response to heat stress. Biochim. Biophys. Acta 1844: 818-828. https://doi.org/10.1016/j.bbapap.2014.02.010

Chirinos R, Galarza J, Betalleluz-Pallardel I, Pedreschi R, et al. (2010). Antioxidant compounds and antioxidant capacity of Peruvian camu camu (Myrciaria dubia (H.B.K.) McVaugh) fruit at different maturity stages. Food Chem. 120: 1019-1024. https://doi.org/10.1016/j.foodchem.2009.11.041

Chua ACNC, Hsiao ESLH, Yang YC, Lin LJ, et al. (2008). Gene families encoding 11S globulin and 2S albumin isoforms of jelly fig (Ficus awkeotsang) Achenes. Biosci. Biotechnol. Biochem. 72: 506-513. https://doi.org/10.1271/bbb.70588

Coelho MB, Macedo MLR, Marangoni S, Silva DS, et al. (2010). Purification of legumin-like proteins from Coffea arabica and Coffea racemosa seeds and their insecticidal properties toward cowpea weevil (Callosobruchus maculatus) (Coleoptera: Bruchidae). J. Agric. Food Chem. 58: 3050-3055. https://doi.org/10.1021/jf9037216

Krewer CdaC, Ribeiro EE, Ribeiro EAM, Moresco RN, et al. (2011). Habitual intake of guaraná and metabolic morbidities: an epidemiological study of an elderly Amazonian population. Phytother. Res. 25: 1367-1374.

Denison FC, Paul AL, Zupanska AK and Ferl RJ (2011). 14-3-3 proteins in plant physiology. Semin. Cell Dev. Biol. 22: 720-727. https://doi.org/10.1016/j.semcdb.2011.08.006

Dorion S, Matton DP and Rivoal J (2006). Characterization of a cytosolic nucleoside diphosphate kinase associated with cell division and growth in potato. Planta 224: 108-124. https://doi.org/10.1007/s00425-005-0199-3

Ellis RJ and van der Vies SM (1991). Molecular chaperones. Annu. Rev. Biochem. 60: 321-347. https://doi.org/10.1146/ annurev.bi.60.070191.001541

Escobar JR, Corrêa MPF and Aguilera FP (1984). Estruturas florais, floração e técnicas para a polinicação controlada do guaranazeiro. Pesqui. Agropecu. Bras. 19: 615-622.

Escobar Galvis ML, Marttila S, Håkansson G, Forsberg J, et al. (2001). Heat stress response in pea involves interaction of mitochondrial nucleoside diphosphate kinase with a novel 86-kilodalton protein. Plant Physiol. 126: 69-77. https:// doi.org/10.1104/pp.126.1.69

Espinola EB, Dias RF, Mattei R and Carlini EA (1997). Pharmacological activity of Guarana (Paullinia cupana Mart.) in laboratory animals. J. Ethnopharmacol. 55: 223-229. https://doi.org/10.1016/S0378-8741(96)01506-1

Faurobert M, Mihr C, Bertin N, Pawlowski T, et al. (2007). Major proteome variations associated with cherry tomato pericarp development and ripening. Plant Physiol. 143: 1327-1346. https://doi.org/10.1104/pp.106.092817

Fraige K, González-Fernández R, Carrilho E and Jorrín-Novo JV (2015). Metabolite and proteome changes during the ripening of Syrah and Cabernet Sauvignon grape varieties cultured in a nontraditional wine region in Brazil. $J$. Proteomics 113: 206-225. https://doi.org/10.1016/j.jprot.2014.09.021

Fransz P and de Jong H (2011). From nucleosome to chromosome: a dynamic organization of genetic information. Plant J. 66: 4-17. https://doi.org/10.1111/j.1365-313X.2011.04526.x

Fulgosi H, Soll J, de Faria Maraschin S, Korthout HAAJ, et al. (2002). 14-3-3 proteins and plant development. Plant Mol. Biol. 50: 1019-1029. https://doi.org/10.1023/A:1021295604109

González RM and Iusem ND (2014). Twenty years of research on Asr (ABA-stress-ripening) genes and proteins. Planta 239: 941-949. https://doi.org/10.1007/s00425-014-2039-9

Görg A, Boguth G, Obermaier C and Weiss W (1998). Two-dimensional electrophoresis of proteins in an immobilized pH 4-12 gradient. Electrophoresis 19: 1516-1519. https://doi.org/10.1002/elps.1150190850

Genetics and Molecular Research 16 (3): gmr16039642 
Vitlin Gruber A, Nisemblat S, Azem A and Weiss C (2013). The complexity of chloroplast chaperonins. Trends Plant Sci. 18: 688-694. https://doi.org/10.1016/j.tplants.2013.08.001

Hanna SL, Sherman NE, Kinter MT and Goldberg JB (2000). Comparison of proteins expressed by Pseudomonas aeruginosa strains representing initial and chronic isolates from a cystic fibrosis patient: an analysis by 2-D gel electrophoresis and capillary column liquid chromatography-tandem mass spectrometry. Microbiology 146: 24952508. https://doi.org/10.1099/00221287-146-10-2495

Horn PJ and Peterson CL (2002). Molecular biology. Chromatin higher order folding - wrapping up transcription. Science 297: 1824-1827. https://doi.org/10.1126/science. 1074200

Huang JC, Lin SM and Wang CS (2000). A pollen-specific and desiccation-associated transcript in Lilium longiflorum during development and stress. Plant Cell Physiol. 41: 477-485. https://doi.org/10.1093/pcp/41.4.477

Iusem ND, Bartholomew DM, Hitz WD and Scolnik PA (1993). Tomato (Lycopersicon esculentum) transcript induced by water deficit and ripening. Plant Physiol. 102: 1353-1354. https://doi.org/10.1104/pp.102.4.1353

Jeanneau M, Gerentes D, Foueillassar X, Zivy M, et al. (2002). Improvement of drought tolerance in maize: towards the functional validation of the $\mathrm{Zm}$-Asr1 gene and increase of water use efficiency by over-expressing C4-PEPC. Biochimie 84: 1127-1135. https://doi.org/10.1016/S0300-9084(02)00024-X

Jimenez-Lopez JC, Melser S, DeBoer K, Thatcher LF, et al. (2016). Narrow-Leafed Lupin (Lupinus angustifolius) $\beta 1$ - and $\beta 6-$ Conglutin Proteins Exhibit Antifungal Activity, Protecting Plants against Necrotrophic Pathogen Induced Damage from Sclerotinia sclerotiorum and Phytophthora nicotianae. Front. Plant Sci. 7: 1856. https://doi.org/10.3389/ fpls.2016.01856

Kalifa Y, Gilad A, Konrad Z, Zaccai M, et al. (2004). The water- and salt-stress-regulated Asr1 (abscisic acid stress ripening) gene encodes a zinc-dependent DNA-binding protein. Biochem. J. 381: 373-378. https://doi.org/10.1042/ BJ20031800

Kennedy DO, Haskell CF, Wesnes KA and Scholey AB (2004). Improved cognitive performance in human volunteers following administration of guarana (Paullinia cupana) extract: comparison and interaction with Panax ginseng. Pharmacol. Biochem. Behav. 79: 401-411. https://doi.org/10.1016/j.pbb.2004.07.014

Kennedy DO, Haskell CF, Robertson B, Reay J, et al. (2008). Improved cognitive performance and mental fatigue following a multi-vitamin and mineral supplement with added guaraná (Paullinia cupana). Appetite 50: 506-513. https://doi.org/10.1016/j.appet.2007.10.007

Kersten B, Bürkle L, Kuhn EJ, Giavalisco P, et al. (2002). Large-scale plant proteomics. Plant Mol. Biol. 48: 133-141. https://doi.org/10.1023/A:1013784205292

Kim JY, Park SJ, Jang B, Jung C-H, et al. (2007). Functional characterization of a glycine-rich RNA-binding protein 2 in Arabidopsis thaliana under abiotic stress conditions. Plant J. 50: 439-451. https://doi.org/10.1111/j.1365313X.2007.03057.x

Kim SY, Paeng SK, Nawkar GM, Maibam P, et al. (2011). The 1-Cys peroxiredoxin, a regulator of seed dormancy, functions as a molecular chaperone under oxidative stress conditions. Plant Sci. 181: 119-124. https://doi.org/10.1016/j. plantsci.2011.04.010

Klein RD, Chidawanyika T, Tims HS, Meulia T, et al. (2014). Chaperone function of two small heat shock proteins from maize. Plant Sci. 221-222: 48-58. https://doi.org/10.1016/j.plantsci.2014.01.012

Kuskoski EM, Roseane F, García AA and Troncoso GAM (2005). Propriedades químicas y farmacológicas del fruto guaraná (Paullinia cupana). Rev. La Fac. Química Farm. 12: 45-52.

Lascu I and Gonin P (2000). The catalytic mechanism of nucleoside diphosphate kinases. J. Bioenerg. Biomembr. 32: 237246. https://doi.org/10.1023/A:1005532912212

Lee K, Park OS, Jung SJ and Seo PJ (2016). Histone deacetylation-mediated cellular dedifferentiation in Arabidopsis. J. Plant Physiol. 191: 95-100. https://doi.org/10.1016/j.jplph.2015.12.006

Lorković ZJ (2009). Role of plant RNA-binding proteins in development, stress response and genome organization. Trends Plant Sci. 14: 229-236. https://doi.org/10.1016/j.tplants.2009.01.007

Majhenič L, Škerget M and Knez Ž (2007). Antioxidant and antimicrobial activity of guarana seed extracts. Food Chem. 104: 1258-1268. https://doi.org/10.1016/j.foodchem.2007.01.074

Maskin L, Gudesblat GE, Moreno JE, Carrari FO, et al. (2001). Differential expression of the members of the Asr gene family in tomato (Lycopersicon esculentum). Plant Sci. 161: 739-746. https://doi.org/10.1016/S0168-9452(01)00464-2

Matamoros MA, Loscos J, Dietz KJ, Aparicio-Tejo PM, et al. (2010). Function of antioxidant enzymes and metabolites during maturation of pea fruits. J. Exp. Bot. 61: 87-97. https://doi.org/10.1093/jxb/erp285

Mattei R, Dias RF, Espínola EB, Carlini EA, et al. (1998). Guarana (Paullinia cupana): toxic behavioral effects in laboratory animals and antioxidants activity in vitro. J. Ethnopharmacol. 60: 111-116. https://doi.org/10.1016/S0378$\underline{8741(97) 00141-4}$

Genetics and Molecular Research 16 (3): gmr16039642 
Maxwell DP, Wang Y, McIntoshi L (1999). The alternative oxidase lowers mitochondrial reactive oxygen production in plant cells. 96: 8271-8276.

Mittler R, Vanderauwera S, Gollery M and Van Breusegem F (2004). Reactive oxygen gene network of plants. Trends Plant Sci. 9: 490-498. https://doi.org/10.1016/j.tplants.2004.08.009

Møller IM, Jensen PE and Hansson A (2007). Oxidative modifications to cellular components in plants. Annu. Rev. Plant Biol. 58: 459-481. https://doi.org/10.1146/annurev.arplant.58.032806.103946

Moon H, Lee B, Choi G, Shin D, et al. (2003). NDP kinase 2 interacts with two oxidative stress-activated MAPKs to regulate cellular redox state and enhances multiple stress tolerance in transgenic plants. Proc. Natl. Acad. Sci. USA 100: 358-363. https://doi.org/10.1073/pnas.252641899

Murase T, Nagasawa A, Suzuki J, Hase T, et al. (2002). Beneficial effects of tea catechins on diet-induced obesity: stimulation of lipid catabolism in the liver. Int. J. Obes. Relat. Metab. Disord. 26: 1459-1464. https://doi.org/10.1038/ sj.ijo.0802141

Nakashima K and Yamaguchi-Shinozaki K (2013). ABA signaling in stress-response and seed development. Plant Cell Rep. 32: 959-970. https://doi.org/10.1007/s00299-013-1418-1

Neill S, Desikan R and Hancock J (2002). Hydrogen peroxide signalling. Curr. Opin. Plant Biol. 5: 388-395. https://doi. org/10.1016/S1369-5266(02)00282-0

Oliveira CT, Kunz D, Silva CP and Macedo MLR (2015). Entomotoxic properties of Dioclea violacea lectin and its effects on digestive enzymes of Anagasta kuehniella (Lepidoptera). J. Insect Physiol. 81: 81-89. https://doi.org/10.1016/j. jinsphys.2015.07.007

Osmark P, Boyle B and Brisson N (1998). Sequential and structural homology between intracellular pathogenesis-related proteins and a group of latex proteins. Plant Mol. Biol. 38: 1243-1246. https://doi.org/10.1023/A:1006060224012

Otero AS (2000). NM23/nucleoside diphosphate kinase and signal transduction. J. Bioenerg. Biomembr. 32: 269-275. https://doi.org/10.1023/A:1005589029959

Peumans WJ and Van Damme EJ (1995). Lectins as plant defense proteins. Plant Physiol. 109: 347-352. https://doi. org/10.1104/pp.109.2.347

Poltronieri MC, Duarte MLR, Rodrigues JELF, Nazaré RFR, et al. (1995). A cultura do guaraná. 1st ed. Brasília, Brazil.

Radauer C, Lackner P and Breiteneder H (2008). The Bet v 1 fold: an ancient, versatile scaffold for binding of large, hydrophobic ligands. BMC Evol. Biol. 8: 286. https://doi.org/10.1186/1471-2148-8-286

Roberts MR (2003). 14-3-3 proteins find new partners in plant cell signalling. Trends Plant Sci. 8: 218-223. https://doi. org/10.1016/S1360-1385(03)00056-6

Rogers WJ, Bézard G, Deshayes A, Meyer I, et al. (1999). Biochemical and molecular characterization and expression of the 11S-type storage protein from Coffea arabica endosperm. Plant Physiol. Biochem. 37: 261-272. https://doi. org/10.1016/S0981-9428(99)80024-2

Saito R, Yamamoto H, Makino A, Sugimoto T, et al. (2011). Methylglyoxal functions as Hill oxidant and stimulates the photoreduction of $\mathrm{O}(2)$ at photosystem I: a symptom of plant diabetes. Plant Cell Environ. 34: 1454-1464. https:// doi.org/10.1111/j.1365-3040.2011.02344.x

Salmona J, Dussert S, Descroix F, de Kochko A, et al. (2008). Deciphering transcriptional networks that govern Coffea arabica seed development using combined cDNA array and real-time RT-PCR approaches. Plant Mol. Biol. 66: 105124. https://doi.org/10.1007/s11103-007-9256-6

Schimpl FC, Kiyota E, Mayer JLS, Gonçalves JFC, et al. (2014). Molecular and biochemical characterization of caffeine synthase and purine alkaloid concentration in guarana fruit. Phytochemistry 105: 25-36. https://doi.org/10.1016/j. phytochem.2014.04.018

Schmidt R and Schippers JHM (2015). ROS-mediated redox signaling during cell differentiation in plants. Biochim. Biophys. Acta 1850: 1497-1508. https://doi.org/10.1016/j.bbagen.2014.12.020

Sekhar K, Priyanka B, Reddy VD and Rao KV (2010). Isolation and characterization of a pigeonpea cyclophilin (CcCYP) gene, and its over-expression in Arabidopsis confers multiple abiotic stress tolerance. Plant Cell Environ. 33: 13241338.

Shewry PR, Napier JA and Tatham AS (1995). Seed storage proteins: structures and biosynthesis. Plant Cell 7: 945-956. https://doi.org/10.1105/tpc.7.7.945

Souza AL, Angelo PCS, Nogueira PPO, Gonçalves JFC, et al. (2014). Method for obtaining high-resolution proteomic analysis from pericarps of guarana. Genet. Mol. Res. 13: 8014-8024. https://doi.org/10.4238/2014.September.29.14

Sun H, Kim MK, Pulla RK, Kim YJ, et al. (2010). Isolation and expression analysis of a novel major latex-like protein (MLP151) gene from Panax ginseng. Mol. Biol. Rep. 37: 2215-2222. https://doi.org/10.1007/s11033-009-9707-z

Tariq M and Paszkowski J (2004). DNA and histone methylation in plants. Trends Genet. 20: 244-251. https://doi. org/10.1016/j.tig.2004.04.005

Genetics and Molecular Research 16 (3): gmr16039642 
Thompson JE, Hopkins MT, Taylor C and Wang TW (2004). Regulation of senescence by eukaryotic translation initiation factor 5A: implications for plant growth and development. Trends Plant Sci. 9: 174-179. https://doi.org/10.1016/j. tplants.2004.02.008

Thompson P, Bowsher CG and Tobin AK (1998). Heterogeneity of mitochondrial protein biogenesis during primary leaf development in barley. Plant Physiol. 118: 1089-1099. https://doi.org/10.1104/pp.118.3.1089

Thornalley PJ (2003). Glyoxalase I--structure, function and a critical role in the enzymatic defence against glycation. Biochem. Soc. Trans. 31: 1343-1348. https://doi.org/10.1042/bst0311343

Tobi SE, Gilbert M, Paul N and McMillan TJ (2002). The green tea polyphenol, epigallocatechin-3-gallate, protects against the oxidative cellular and genotoxic damage of UVA radiation. Int. J. Cancer 102: 439-444. https://doi. org/10.1002/ijc. 10730

Trandinh CC, Pao GM and Saier MH, Jr. (1992). Structural and evolutionary relationships among the immunophilins: two ubiquitous families of peptidyl-prolyl cis-trans isomerases. FASEB J. 6: 3410-3420.

Vandenborre G, Smagghe G and Van Damme EJM (2011). Plant lectins as defense proteins against phytophagous insects. Phytochemistry 72: 1538-1550. https://doi.org/10.1016/j.phytochem.2011.02.024

Wang W-Q, Liu S-J, Song S-Q and Møller IM (2015). Proteomics of seed development, desiccation tolerance, germination and vigor. Plant Physiol. Biochem. 86: 1-15. https://doi.org/10.1016/j.plaphy.2014.11.003

Wang Y, Yang L, Chen X, Ye T, et al. (2016). Major latex protein-like protein 43 (MLP43) functions as a positive regulator during abscisic acid responses and confers drought tolerance in Arabidopsis thaliana. J. Exp. Bot. 67: 421-434. https://doi.org/10.1093/jxb/erv477

Yang DH, Kwak KJ, Kim MK, Park SJ, et al. (2014). Expression of Arabidopsis glycine-rich RNA-binding protein AtGRP2 or AtGRP7 improves grain yield of rice (Oryza sativa) under drought stress conditions. Plant Sci. 214: 106112. https://doi.org/10.1016/j.plantsci.2013.10.006

Yi X, Hargett SR, Frankel LK and Bricker TM (2009). The PsbP protein, but not the PsbQ protein, is required for normal thylakoid architecture in Arabidopsis thaliana. FEBS Lett. 583: 2142-2147. https://doi.org/10.1016/j. febslet.2009.05.048

Genetics and Molecular Research 16 (3): gmr16039642 